\title{
Season, Environment Stress and Refrigerated Storage Affect Genomic DNA Isolation of Tung Tree
}

\author{
Lingling Zhang ${ }^{1,2,3}$, Yue Pan ${ }^{1,2,3}$, Jinmin Fu ${ }^{1,2}$, Junhua Peng ${ }^{1,2 *}$ \\ ${ }^{1}$ Wuhan Botanical Garden, Chinese Academy of Sciences, Wuhan, China; ${ }^{2}$ Key Lab of Plant Germplasm Enhancement and Specialty \\ Agriculture, Chinese Academy of Sciences, Wuhan, China; ${ }^{3}$ Graduate University of Chinese Academy of Sciences, Beijing, China. \\ Email: ${ }^{*}$ jpeng@lamar.colostate.edu, junhuapeng@yahoo.com
}

Received August $11^{\text {th }}, 2012$; revised September $19^{\text {th }}, 2012$; accepted October $6^{\text {th }}, 2012$

\begin{abstract}
Many metabolites in leaf tissue disturbed plant genomic DNA isolation and they always varied when leaf was harvested from different environments. Objective of this study was to investigate whether season, environment stress and refrigerated storage affect genomic DNA isolation of tung tree leaves. Five types of young leaves and two DNA isolation protocols, the recycling CTAB protocol I and II, were adopted to carry out the experiment. Our results showed that both leaf type and protocol affected DNA isolation of tung tree. Using the recycling CTAB protocol II, though little DNA were obtained from three types of young leaves, though the other two have satisfying results. Whereas the recycling CTAB protocol I could produce high yield genomic DNA from all the five types of young leaves. All the detectable DNA samples in agarose gel electrophoresis were good templates for PCR reaction. Season, environment stress and refrigerated storage had a big effect on genomic DNA isolation of tung tree. The recycling CTAB protocol I was proved to be an effective and universal protocol for DNA isolation of tung tree. Five types of young leaves could all act as the tissue for isolation of genomic DNA, but the summer healthy young leaves without long-time refrigerated storage are the best. The optimal leaf tissue will benefit DNA isolation of plant species.
\end{abstract}

Keywords: Tung Tree; Vernicia fordii; DNA Isolation; Season; Environment Stress; Storage

\section{Introduction}

Plant often produces many metabolites, such as polysaccharides, polyphenols, protein and tannin. These compounds always interfere with DNA isolation and downstream DNA-based experiments [1-6]. To date, lots of DNA isolation protocols have been published and aimed at eliminating the negative effects of biochemical components on DNA isolation [7-17]. However, DNA isolation is still a challenge for many plant species.

Chemotypic heterogeneity among different species did not allowed the direct application of an extraction protocol for a species to other species [17-19]. Metabolites in plant leaves were not stable, changing with many factors, such as leaf age [19-21], season [22-24], light intensity [25] and environmental stress [26,27]. Leaf age was reported to affect the properties of extracted DNA, which was inferred to be related with the accumulation of defense compounds during the leaf development [19]. Environmental factors such as light intensity, temperature and seasonal variance were reported to affect the production of polysaccharide [25], phenolic compounds [28,29] and other metabolites in leaves. However, up to now,

*Corresponding author. little reports were about the effect of theses environmental factors on DNA isolation of plant species.

Tung tree (Vernicia fordii), belonging to Euphorbiaceae, is an oil-producing plant with multiple uses especially its potential in biodiesel production [30-32]. DNA extraction is essential for molecular genetic analyses and marker-assisted improvement of this oil-producing species. In present study, we found that season, environment stress and refrigerated storage all had big effect on genomic DNA isolation of tung tree. Besides, the recycling CTAB protocol I was proved to be a universal method for DNA isolation of tung tree.

\section{Materials and Protocols}

\subsection{Materials}

Young leaves were harvested from healthy tung tree at different seasons, in the autumn (early November in 2009), spring (early April in 2010) and summer (July in 2010), respectively (hereafter called autumn healthy leaves, spring healthy leaves and summer healthy leaves for short). Besides, leaves were also harvested from the tung tree that suffered from both transplant and waterdrown stress in the summer of 2010 (hereafter called 
summer stressed leaves for short). These four types of leaf tissues were ground into fine powder in liquid nitrogen, and then $0.3 \mathrm{~g}$ of powders for each leaf tissue type were immediately used to isolate genomic DNA. Besides, some other summer healthy leaf tissues were stored in freezer for three months and then was used to isolate genomic DNA. Tissue powder was a mixture of several genotypes. Unless state, the leaf referred to the young leaf without the refrigerated storage in the text below.

\subsection{Protocols}

Two protocols (Lingling Zhang et al., unpublished) were adopted to extract DNA from the five types of tung tree young leaves. The main procedures of recycling CTAB protocol I was followed. 1) Add $1.5 \mathrm{~mL}$ of wash buffer to $0.3 \mathrm{~g}$ of ground leaf sample. Mix well and place at the low temperature with occasional swirling for at least 15 min. Then centrifuge at $12,000 \mathrm{rpm}$ for $15 \mathrm{~min}$. Discard the supernatant. The tissue pretreatment was carried out for three times; 2) Add $0.5 \mathrm{~mL}$ of CTAB extraction buffer and re-suspend tissue pellet. Incubate at $65^{\circ} \mathrm{C}$ for $40 \mathrm{~min}$. Centrifuge at 12,000 rpm for $15 \mathrm{~min}$. Transfer the supernatant to a new tube; 3) Add $200 \mu \mathrm{L}$ Chloroform-isoamylalcohol (24:1). Mix well and let stand for several minutes. Centrifuge at $12,000 \mathrm{rpm}$ for $15 \mathrm{~min}$ and transfer the supernatant to a new $1.5 \mathrm{~mL}$ tube carefully; 4) Precipitate the DNA by adding two volumes of cold absolute ethanol and incubate for $30 \mathrm{~min}$ at $-20^{\circ} \mathrm{C}$. Transfer the DNA precipitation with a tip and wash it with $70 \%$ ethanol for $30 \mathrm{~min}$, better for overnight. Then pour off the ethanol; 5) Dry the DNA and dissolve it in $100 \mu \mathrm{L}$ $\mathrm{T}_{0.1} \mathrm{E}$. Add $1 \mu \mathrm{L}$ of $10 \mu \mathrm{g} / \mathrm{mL}$ ribonuclease. Incubate the DNA solution at $37^{\circ} \mathrm{C}$ for $30 \mathrm{~min}$, and then incubate at $65^{\circ} \mathrm{C}$ for $15 \mathrm{~min}$. This DNA sample was termed as the first DNA (1st DNA); 6) Similarly, treat the residual pellets in the above step 2) for other three cycles of the step 2) to the step 5). Correspondingly, the resulted DNA samples were termed as the second DNA (2nd DNA), third DNA (3rd DNA) and fourth DNA (4th DNA), respectively. The recycling CTAB protocol II shared all the procedure of the recycling CTAB protocol I except that the tissue pretreatment was only carry out for one time.

\subsection{DNA Isolation and Assessment}

The quality and yield of extracted DNA were determined by agarose gel electrophoresis. Concentration of DNA samples was assessed as the following. $2 \mu \mathrm{L}$ of DNA solution for each sample was added into $48 \mu \mathrm{L}$ of sterilized water (mix well). Then $5 \mu \mathrm{L}$ of the diluted DNA solution plus $5 \mu \mathrm{L}$ of $2.5 \mathrm{X}$ loading buffer was loaded into $0.8 \%$ agrose gel and run in $0.5 \mathrm{X}$ TBE buffer $(\mathrm{pH} 8.0)$ at room temperature. The gel was visualized with ethidum bormide staining. DNA quantity for each lane/sample was estimated by comparing band intensity with the concentration-known $\lambda$ DNA standards (Promega, Madison, WI, USA). DNA concentration was calculated using formula, concentration $=$ [quantity $(\mathrm{ng})$ of $5 \mu \mathrm{L}$ diluted $\mathrm{DNA} / 5 \mu \mathrm{L} \times$ dilution factor $(50 / 2=25)]$.

\subsection{Polymerase Chain Reaction Amplification}

Coding region cloning of fad 2 gene was performed using PCR approach. On the basis of GenBank sequence AF525534, sequences of primers for PCR amplification are 5'-GATGGGTGCTGGTGGCAGAATGTCA-3' and 5'-CCAGAACTTCCAAGCCCTTCACTTTTG -3' [33], which amplify an approximately $1.2 \mathrm{~kb}$ fragment encompassing the entire coding region of fad 2 gene. The PCR were performed in a $25 \mu \mathrm{L}$ reaction volume $(60 \mathrm{ng}$ template DNA, $0.4 \mu \mathrm{M}$ specific primers, $1 \mathrm{U}$ Taq DNA polymerase, $0.2 \mathrm{mM}$ dNTP mixture, $1 \times$ PCR buffer, 0.15 $\mathrm{mM} \mathrm{Mg}^{2+}$ ) using BIORAD-My Cycle Thermocyclers (Bio-Rad Laboratories, Inc., California, USA) with the following program: pre-denaturation at $94^{\circ} \mathrm{C}$ for $4 \mathrm{~min}$; 30 cycles of denaturation at $94^{\circ} \mathrm{C}$ for $45 \mathrm{~s}$, annealing at $65^{\circ} \mathrm{C}$ for $45 \mathrm{~s}$, extension at $72^{\circ} \mathrm{C}$ for $60 \mathrm{~s}$; and a final extension step at $72^{\circ} \mathrm{C}$ for $10 \mathrm{~min}$, then hold on for $15 \mathrm{~min}$ at $4^{\circ} \mathrm{C}$. Then PCR products were separated in $1 \%$ agarose gels and the gel was visualized with ethidium bromide staining.

\section{Results}

\subsection{Comparisons of DNA Samples Isolated From Five Types of Leaves Using the Protocol I}

Using agarose gel electrophoresis and $\lambda$ DNA of known concentration as standards, concentration of DNA samples produced by the protocol I were determined. As shown in table 1, yield of the 1st DNA varied for the five types of young leaves, about $200 \mathrm{ng} / \mu \mathrm{L}$ both for spring healthy leaf and summer healthy leaf, $100 \mathrm{ng} / \mu \mathrm{L}$ for summer stressed leaf, but little DNA for summer healthy leaf with three-month refrigerated storage and autumn healthy leaf (Figure 1). As shown in Figure 1, the 2nd, 3rd and 4th DNA for each type of leaf were all obviously detectable in agrose gel electrophoresis, the concentration of these DNA samples ranging from $300 \mathrm{ng} / \mu \mathrm{L}$ to $500 \mathrm{ng} / \mu \mathrm{L}$ (Table 1). These data indicated that the protocol I could be successfully applied to different types of young leaves without significant differences.

\subsection{Comparisons of DNA Samples Isolated from Five Types of Leaves Using the Protocol II}

However using the recycling CTAB method II, DNA samples extracted from the five types of leaves greatly 


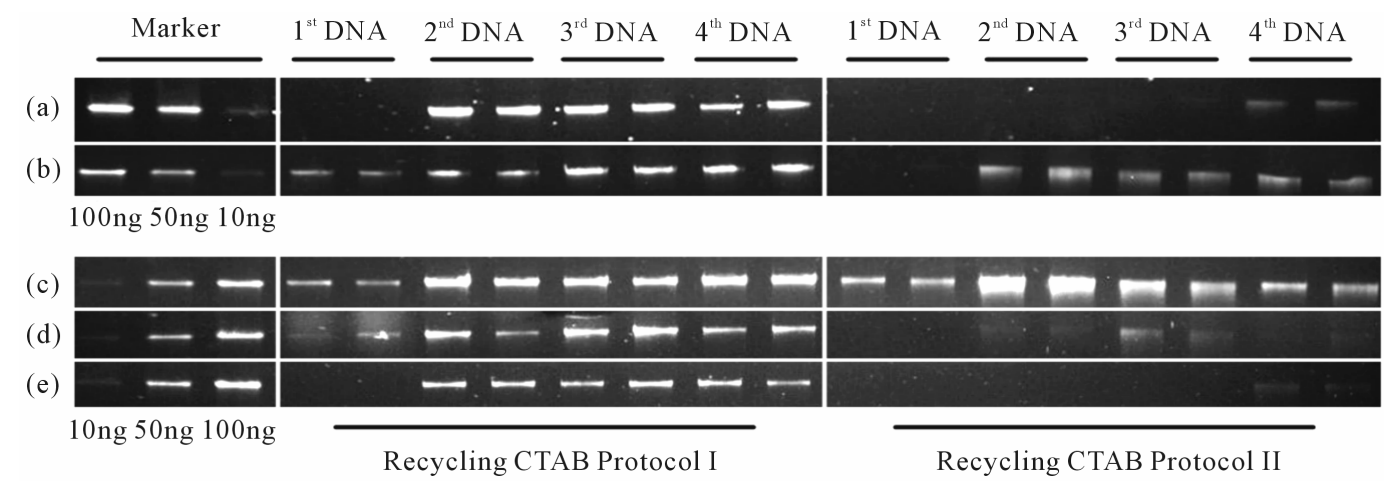

Figure 1. Agarose gel electrophoresis of genomic DNA isolated from five types of young leaves using two protocols. (a) Autumn healthy leaf; (b) Spring healthy leaf; (c) Summer healthy leaf; (d) Summer stressed leaf; (e) Summer healthy leaf with three-month refrigerated storage.

Table 1. Concentration of DNA samples for the five types of young leaves using the two protocols.

\begin{tabular}{|c|c|c|c|c|c|c|c|c|c|}
\hline \multirow{2}{*}{ Protocol } & \multirow{2}{*}{ Leaf Type } & \multicolumn{4}{|c|}{ C1 (ng) } & \multicolumn{4}{|c|}{$\mathrm{C} 2(\mathrm{ng} / \mu \mathrm{L})$} \\
\hline & & $1 \mathrm{st}$ & 2nd & $3 \mathrm{rd}$ & 4 th & 1 st & 2 nd & $3 \mathrm{rd}$ & 4 th \\
\hline \multirow{5}{*}{$\begin{array}{c}\text { Recycling CTAB } \\
\text { Protocol I }\end{array}$} & $\mathrm{a}$ & 1 & 100 & 100 & 100 & 1 & 500 & 500 & 500 \\
\hline & $\mathrm{b}$ & 40 & 100 & 100 & 100 & 200 & 500 & 500 & 500 \\
\hline & $\mathrm{c}$ & 40 & 100 & 100 & 100 & 200 & 500 & 500 & 500 \\
\hline & $\mathrm{d}$ & 20 & 60 & 100 & 80 & 100 & 300 & 500 & 400 \\
\hline & $\mathrm{e}$ & 1 & 60 & 60 & 60 & 1 & 300 & 300 & 300 \\
\hline \multirow{5}{*}{$\begin{array}{l}\text { Recycling CTAB } \\
\text { Protocol II }\end{array}$} & $\mathrm{a}$ & 1 & 1 & 1 & 20 & 1 & 1 & 1 & 100 \\
\hline & $\mathrm{b}$ & 1 & 60 & 60 & 60 & 1 & 300 & 300 & 300 \\
\hline & $\mathrm{c}$ & 60 & 150 & 80 & 60 & 300 & 750 & 400 & 300 \\
\hline & $\mathrm{d}$ & 1 & 10 & 20 & 1 & 1 & 50 & 100 & 1 \\
\hline & $\mathrm{e}$ & 1 & 1 & 1 & 10 & 1 & 1 & 1 & 50 \\
\hline
\end{tabular}

$\mathrm{C} 1$, DNA quantity (ng) in $5 \mu \mathrm{L}$ of diluted solution loaded into agaroe gel estimated by comparison with the standard $\lambda \mathrm{DNA}$ of known content, $50 \mathrm{ng}$; $\mathrm{C}$, DNA concentration $(\mathrm{ng} / \mu \mathrm{L})$ estimated using agarose gel electrophoresis and calculated as $\mathrm{C} 2 / 5 \mu \mathrm{L}$ (volume of the loaded DNA dissolution) $\times 25$ (dilution factor). Four DNA samples were isolated from a single sample. 1st, 2nd, 3rd and 4th represent the first DNA samples, the secondary DNA samples, the third DNA samples and the four DNA samples, respectively. Lowercase letter a, b, c, d and e represent the autumn healthy leaf, spring healthy leaf, summer healthy leaf, summer stressed leaf and summer healthy leaf with three-month refrigerated storage, respectively. The slashes in the tables represent the DNA samples which could not be detectable in agarose gel electrophoresis.

varied in yield. First, for autumn healthy leaf, the first three of the four DNA samples were not detectable and concentration of the 4 th DNA was about $100 \mathrm{ng} / \mu \mathrm{L}$ (Figure 1 and Table 1). Secondly, for spring healthy leaf, the 1 st DNA was not detectable but 2nd, 3rd and 4th DNAsamples were all detectable, each about $300 \mathrm{ng} / \mu \mathrm{L}$. Thirdly, all the four DNA samples for summer healthy leaf were detectable, and concentration of 1st to 4th DNA was about $300 \mathrm{ng} / \mu \mathrm{L}, 750 \mathrm{ng} / \mu \mathrm{L}, 400 \mathrm{ng} / \mu \mathrm{L}$, and $300 \mathrm{ng} / \mu \mathrm{L}$, respectively (Table 1). Fourthly, for the summer stressed leaf, the 1st and 4th DNA samples was not detected in agarose gel while the band of the 2nd and 3rd DNA samples were very weak, apparently different from the four bright bands of summer healthy leaf above. Last, for the summer leaf with three months refrigerated storage, only the 4th DNA of the four samples was detectable but the concentration was relatively low, about $50 \mathrm{ng} / \mu \mathrm{L}$. These data indicated that the protocol II could not be applied to the different types of young leaf and also demonstrate the biochemical components for the five types of young leaf tissues were greatly varied.

\subsection{Analysis of DNA Quality by PCR Amplifycation of Fad2 Gene}

For the four DNA samples of a tissue sample, the DNAdetectable samples were mixed into one DNA sample with an exception for the four DNA samples of the summer healthy leaves. Thus, using the two protocols, 
eight DNA-incorporated samples were obtained from the four types of leaves and eight DNA samples were got from the summer healthy leaf. These sixteen DNA samples were all used as the templates to amplify fad2 gene. As shown in Figure 2, the target bands for all the sixteen DNA samples were visible and distinct, and were the expected size of fad 2 gene fragments $(1.2 \mathrm{kbp})$ targeted by the primers used, indicating that all the sixteen DNA samples had enough purity for fad 2 gene cloning.

\section{Discussion}

\subsection{Factors Affecting Genomic DNA Isolation of Tung Tree}

Leaves were the main source of DNA isolation. Many metabolites in leaves interfere with isolation of clean DNA. These metabolites in leaves were in mobile droved by the exogenous and endogenous signals. Defense compounds like polyphenols and tannin were reportedly largely produced and accumulated when plants were in the stress $[28,29]$. Leave development also had a big effect on the composition of biochemical components in leaves [19-22,34]. The matured tree leaves were reported to be difficult in DNA isolation for its thick cell wall, and high content secondary metabolites [18]. Leaf age of Fabaceae (Dimorphandra mollis) was reported to affect DNA isolation, in which DNA was successfully isolated from the young but failed from the old leaves, which was inferred to be attributed to the differently cumulative amount of chemical defenses such as tannins and phenols during leaf development [19]. In this study, five types of young leaves of tung tree were harvested in different seasons or environments. Using the recycling $\mathrm{CTAB}$ method II, the greatly varied DNA yield indicated the season for leaf harvest, environment stress and refrigerated storage all had big effect on DNA isolation. In conclusion, it will benefit DNA isolation if taking the environments, such as seasons into account at the step of leaf harvesting.

\subsection{An Effective and Universal Method for DNA Isolation of Tung Tree}

Chemotypic heterogeneity in different species didn't allow the direct application of an extraction protocol for a specific species to other species [19,35]. In present study, chemotypic heterogeneity did not affect the application of protocol I among the five types of young leaf, but seriously disturb the application of the protocol II. It could conclude that the protocol I is an effective and universal method for DNA isolation of tung tree. The only difference between the two protocols is focused on the time of tissue pretreatment, which was carried out for three times for protocol I but one once for protocol II. Hence, it highlighted the importance of efficient elimi-

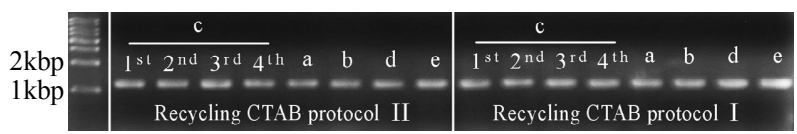

Figure 2. Agarose gel electrophoresis of fad2 gene fragment. Lowercase letter a, b, c, d and e represent the autumn healthy leaf, spring healthy leaf, summer healthy leaf, summer stressed leaf and summer healthy leaf with threemonth refrigerated storage, respectively.

nating the secondary compounds on DNA isolation. As discussed above, we choose the optimal leaves for DNA isolation to reduce difficulties in DNA isolation. However, the leaves available were always limited by various reasons and we have to isolate the DNA from the leaves with various backgrounds. Therefore, a universal DNA isolation protocol is expected for the species of interested.

\section{Acknowledgements}

This work was supported by the National Natural Science Foundation of China (NSFC) Grant Nos. 31030055 and 30870233, Chinese Academy of Sciences under the Important Directional Program of Knowledge Innovation Project Grant No. KSCX2-YW-Z-0722.

\section{REFERENCES}

[1] D. V. Jobes, D. L. Hurley and L. B. Thien, "Plant DNA Isolation: A Method to Efficiently Remove Polyphenolics, Polysaccarides, and RNA," Taxon, Vol. 44, 1995, pp. 379-386.

[2] R. N. Pandey, R. P. Adams and L. E. Flournoy, "Inhibitions of Random Amplified Polymorphic DNAs (RAPDs) by Plant Polysaccarides," Plant Molecular Biology Reporter, Vol. 14, No. 1, 1996, pp. 17-22. doi:10.1007/BF02671898

[3] S. Porebski , L. G. Bailey and B. R. Baum, "Modification of a CTAB DNA Extraction Protocol for Plants Containing High Polysaccharide and Polyphenol Components," Plant Molecular Biology Reporter, Vol. 15, No. 1, 1997, pp. 8-15. doi:10.1007/BF02772108

[4] L. D. Shepherd and T. G. Mclay, "Two Micro-Scale Protocols for the Isolation of DNA from Polysaccharide-Rich Plant Tissue," Journal of Plant Research, Vol. 124, No. 2, 2011, pp. 311-314. doi:10.1007/s10265-010-0379-5

[5] D. M. Yin, H. Y. Liu, X. G. Zhang and D. Q. Cui, “A Protocol for Extraction of High-Quality RNA and DNA from Peanut Plant Tissues," Molecular Biotechnology, Vol. 49, No. 2, 2011, pp. 187-191. doi:10.1007/s12033-011-9391-9

[6] P. Sharma and S. D. Purohit, "An Improved Method of DNA Isolation from Polysaccharide Rich Leaves of Boswellia serrata Roxb," Indian Journal of Biotechnology, Vol. 11, No. 1, 2012, pp. 67-71.

[7] J. Marmur, "A Procedure for the Isolation of Deoxyribonucleic Acid from Micro-Organism," Journal of Molecu- 
lar Biology, Vol. 3, No, 2, 1961, pp. 208-218.

[8] M. G. Murray and W. F. Thompson, "Rapid Isolation of High Molecular Weight Plant DNA," Nucleic Acids Research, Vol. 8, No. 19, 1980, pp. 4321-4325. doi:10.1093/nar/8.19.4321

[9] J. J. Doyle and J. L. Doyle, "Isolation of Plant DNA from Fresh Tissue," Focus, Vol. 12, No. 1, 1990, pp. 13-15.

[10] D. Goldenberger, I. Perschil, M. Ritzler and M. Altwegg, "A Simple Universal DNA Extraction Procedure Using SDS and Proteinase K Is Compatible with Directly PCR Amplification," Genome Research, Vol. 4, 1995, pp. 368370.

[11] S. M. Aljanabi and I. Martinez, "Universal and Rapid Salt-Extraction of High Quality Genomic DNA for PCRBased Techniques," Nucleic Acids Research, Vol. 25, No. 22, 1997, pp. 4692-4693. doi:10.1093/nar/25.22.4692

[12] N. Stein, G. Herren and B. Keller, "A New DNA Extraction Method for High-Throughput Marker Analysis in a Large-Gemone such as Triticum aestivum," Plant Breeding, Vol. 120, No. 4, 2001, pp. 354-356. doi:10.1046/j.1439-0523.2001.00615.x

[13] K. L. Hill-Ambroz, G. L. Brown-Guedira and J. P. Fellers, "Modified Rapid DNA Extraction Protocol for High throught Microsatellite Analysis in Wheat," Crop Science, Vol. 42, No. 6, 2002, pp. 2088-2091. doi:10. 2135/cropsci2002.2088

[14] R. J. Mogg and J. M. Bond, "A Cheap, Reliable and Rapid Method of Extracting High-Quality DNA from Plants," Molecular Ecology Notes, Vol. 3, No. 4, 2003, pp. 666-668. doi:10.1046/j.1471-8286.2003.00548.x

[15] G. C. Allen, M. A. Flores-Vergara, S. Krasynanski, S. Kumar and W. F. Thompson, "A Modified Protocol for Rapid DNA Isolation from Plant Tissues Using Cetyltrimethylammonium Bromide," Nature Protocol, Vol. 1, No. 5, 2006, pp. 2320-2325.

[16] J. Amani, R. Kazemi, A. R. Abbasi and A. H. Salmanian, "A Simple and Rapid Leaf Genomic DNA Extraction Method for Polymerase Chain Reaction Analysis," Iranian Journal of Biotechnology, Vol. 9, No. 1, 2011, pp. 69-71.

[17] H. A. Souza, L. A. Muller, R. L. Brandao and M. B. Lovato, "Isolation of High Quality and PolysaccharideFree DNA from Leaves of Dimorphandra mollis (Leguminosae), a Tree from the Brazilian Cerrado," Genetic Molecular Research, Vol. 11, No. 1, 2012, pp. 756-764.

[18] F. Lefort and G. C. Douglas, "An Efficient Micro-Method of DNA Isolation from Mature Leaves of Four Hardwood Tree Species Acer, Fraxinus, Prunus and Quercu," Annual Forest Science, Vol. 56, No. 3, 1999, pp. 259-263. doi:10.1051/forest: 19990308

[19] P. A. Moreira and D. A. Oliveira, "Leaf Age Affects the Quality of DNA Extracted from Dimorphandra mollis (Fabaceae), a Tropical Tree Species from the Cerrado Region of Brazil," Genetic Molecular Research, Vol. 10, No. 1, 2011, pp. 353-358. doi:10.4238/vol10-1gmr1030

[20] N. M. Van Dam, R. Verpoorte and E. Van der Meljden, "Extreme Difference in Pyrrolizidine Alkaloid Levels between Leaves of cynoglossum officinale," Phytochem- istry, Vol. 37, No. 4, 1994, pp. 1013-1016. doi:10.1016/S0031-9422(00)89519-9

[21] M. A. Azmat, I. A. Khan and H. M. N. Cheema, "Extraction of DNA Suitable for PCR Applications from Mature Leaves of Mangifera indica L.," Journal of Zhejiang University Science B., Vol. 13, No. 4, 2012, pp. 239-243. doi:10.1631/jzus.B1199194

[22] Z. Liu, S. B. Carpenter, W. J. Bourgeois, Y. Yu, R. J. Constantin, M. J. Falcon and J. C. Adams, "Variations in the Secondary Metabolite Camptothecin in Relation to Tissue Age and Season in Camptotheca acuminate," Tree Physiology, Vol. 18, No. 4, 1998, pp. 265-270.

[23] F. Vallejo, F. A. Tomas-Barberan and C. Garcia-Viguera, "Effect of Climatic and Sulphur Fertilization Conditions, on Phenolic Compounds and Vitamin C, in the Inflorescences of Eight Broccoli Cultivars," European Food Research and Technology, Vol. 216, No. 5, 2003, pp. 395401. doi:10.1007/s00217-003-0664-9

[24] M. C. Shih, C. M Chang, S. M. Kang and M. L. Tsai, "Effect of Different Parts (Leaf, Stem and Stalk) and Season (Summer and Winter) on the Chemical Compositions and Antioxidant Activity of Moringa oleifera," International Journal of Molecular Sciences, Vol. 12, No. 9, 2011, pp. 6077-6088. doi:10.3390/ijms12096077

[25] Z. Yang, L. L. Geng, W. Wei and J. Zhang, "Combined Effects of Temperature, Light Intensity, and Nitrogen Concentration on the Growth and Polysaccharide Content of Microcystis aeruginosa in Batch Culture," Biochemical Systematics and Ecology, Vol. 41, 2012, pp. 130-135. doi:10.1016/j.bse.2011.12.015

[26] N. Benhamou, "Elicitor-Induced Plant Defence Pathways," Trends Plant Science, Vol. 1, No. 7, 1996, pp. 233-240. doi:10.1016/1360-1385(96)86901-9

[27] F. Bourgaud, A. Gravot, S. Milesi and E. Gontier, "Production of Plant Secondary Metabolites: A Historial Perspective," Plant Science, Vol. 161, No. 5, 2001, pp. 839851. doi:10.1016/S0168-9452(01)00490-3

[28] T. Siatka and M. Kasparova, "Seasonal Variation in Total Phenolic and Flavonoid Content and DPPH Scavenging Activity of Bellis perennis L. Flowers," Molecular, Vol. 15, No. 12, 2010, pp. 9450-9461.

[29] A. S. Rodrigues, M. R. Perez-Gregorio, M. S. GarciaFalcon, J. Simal-Gandara and D. P. F. Almeida, "Effect of Meteorological Conditions on Antioxidant Flavonoids in Portuguese Cultivars of White and Red Onions," Food Chemistry, Vol. 124, No. 1, 2011, pp. 303-308. doi:10.1016/j.foodchem.2010.06.037

[30] J. Y. Park, D. K. Kim, Z. M. Wang, P. Lu, S. C. Park and J. S. Lee, "Production and Characterization of Biodiesel from Tung Oil," Applied Biochemistry and Biotechnology, Vol. 148, No. 6, 2008, pp. 109-117. doi:10.1007/s12010-007-8082-2

[31] Q. Shang, W. Jiang, H. F. Lu and B. Liang, "Properties of Tung Oil Biodiesel and Its Blends with $0^{\#}$ Diesel," Bioresource Technology, Vol. 101, No. 2, 2010, pp. 826-828. doi:10.1016/j.biortech.2009.08.047

[32] Y. H. Chen, J. H. Chen and Y. M. Luo, "Complementary Biodiesel Combination from Tung and Medium-Chain 
Fatty Acid Oils," Renewable Energy, Vol. 44, 2012, pp. 305-310. doi:10.1016/j.renene.2012.01.098

[33] J. M. Dyer, D. C. Chapital, J. C. Kuan, R. T. Mullen, C. Turner, T. A. McKeon and A.B. Pepperman, "Molecular Analysis of a Bifunctional Fatty Acid Conjugase/Desaturase from Tung: Implications for the Evolution of Plant Fatty Acid Diversity," Plant Physiology, Vol. 130, No. 4, 2002, pp. 2027-2038. doi:10.1104/pp.102.010835

[34] Y. Chen and T. M. Poland, "Interactive Influence of Leaf
Age, Light Intensity, and Girdling on Green Ash Foliar Chemistry and Emerald Ash Border Development," Journal of Chemical Ecology, Vol. 35, 2009, pp. 806-815.

[35] L. Drabkova, J. Kirschner and C.Vlcek, "Comparison of Seven DNA Extraction and Amplification Protocols in Historical Herbarium Specimens of Juncaceae," Plant Molecular Reporter, Vol. 20, No. 2, 2002, pp. 161-175. doi:10.1007/BF02799431. 